\title{
International terrorism as an instrument of political struggle and of injury to integrational law
}

\author{
Pablo Henrique Cordeiro Lessa ${ }^{1 *}$ and Sandra Regina Martini ${ }^{2}$
}

\author{
* Correspondence: \\ pablolessadv@gmail.com; \\ pabloagapinho@hotmail.com \\ ${ }^{1} 93$ Lopo Gonçalves Street - Cidade \\ Baixa, Porto Alegre, RS Zip Code: \\ 90.040-000, Brazil \\ Full list of author information is \\ available at the end of the article
}

\begin{abstract}
International Terrorism happens since old ages, when it was classified as acts against the monarch. Only in modern age, it was classified as political crime committed against the State. However, despite the occurrence since ancient times, the topic gained practice importance in the International Agenda only after the international repercussion of September 11th. At this time, many researches described the political aspect of it, disregarding the economic scenario, especially considering the State interventionism that is taken to avoid economic chaos. Indeed, the State function is also discussed in order to understand how it may keep Social Welfare. This practice instils in collective perspective the association of terrorism with specific ethnic and religious groups, indirectly supporting a nationalist mentality that tends to be exploited by populist governments. This creates a bad view over resistant movements, in which are included the Third World Countries Movements, such as TWAIL, that contests the international balance of power.
\end{abstract}

\section{Introduction}

Terrorist practices have not begun so recently. Souza (2008) points out that during the Roman Empire there was a change of attitude regarding the stability of different beliefs and cultures. According to her, there was a denial in accepting religious plurality since the emergence of monotheistic religions. This led to persecution and the Empire's decline due to the rise of conflicts.

The idea of Terrorism as political offense was brought in French Revolution and persists until today as its main cause, involving crimes against State security and aggression against internal and external national security. Only after the understanding of political crime concept autonomously of common crimes, according to Ferreira (1982, p. 18), the Modern State was considered as its victim, and not anymore the monarchy.

This highlights the need to emphasize the character of terrorism stemming from the political struggle, in which some actors fail to gain control or approve their views on the domestic scene. Then, what ended up was the use of terrorist practices in order to achieve certain status and space within the political environment.

But this was not the only way of operation for terrorist cells. After long years of European colonialism in several countries and the new facet of national domination expressed by Imperialism, some resistant groups decided to denied the acceptation of 
domination and to attempt of cultural control over their beliefs and ways of life, acting clandestinely and violently, at the same time that put at risk other actors who were not involved in this conflict.

Thus, the present paper focus on the research question: has Terrorism increased because it is seen as a form of political struggle? If so, it is also necessary to supplement the question from the analysis of why the main elements of global social appeasement International Law - has not reached its objective, and whether there is still a possibility of reversing this situation. International Law in fact did not accomplish what was set out to do and did not proved itself to be free of external influences and to be a promoter of material equality among nations.

Indeed, it is necessary to emphasize that the main aim of this paper is to describe how terrorism reached the status of political struggle. TWAIL was chosen to clarify this understanding - Third World Approaches in International Law - a movement born at Harvard University in which several theorists contest institutes of International Law and International Organizations in promoting a plural and democratic global society. For these scholars, Eurocentrism was adapted to this new scenario and an effective rupture of the secondary character of Third World countries has not yet been achieved.

Unfortunately, International Law and the organization of global society have not yet been shown to be able to prevent phenomena such as Terrorism, highlighting the urgency and relevance of the topic. The universal peace model, used to justify the use of force, does not represent the conflicting character of society. Unfortunately, it also reduces the voice of some social groups, and indirectly, collaborates to the search for alternative solutions by them.

Thus, the article has been divided into sections that touch on the main points of the discussion. The first is the relation of terrorism to political struggle. In continuity, the influence of Eurocentric paradigm on International Law is highlighted, removing the idea of exemption and neutrality.

After the complete understanding that international law is still vain with various colonialist and imperialist elements, it is urgent to make clear the perspective of resistance groups - how they face international law in pursuit of its objectives, and which are the possible improvements on it.

In the final stretch, the TWAIL movement is presented. Its importance for understanding terrorism is crucial because it seeks to highlight the importance of peripheral countries on international arena, meeting the objectives of some terrorist organizations, despite the use of completely antagonistic means.

Finally, the connections between terrorism and globalization are presented in order to explain that it will be hard to have a different result in relation to terrorism if there is no break with what has been experienced until now, leading to the adoption of State Interventionism legalized by Law.

\section{Brief concept of terrorism}

To understand the subject of terrorism, it is imperative to understand what it is about. In this sense, highlights the difficulty in differentiating what is, in fact, terrorism, and what is usually termed terrorism. Terrorism is, for (pp. 281-282), the "pragmatism of militant organizations that use this resource". 
In the sphere of States, there is also a different definition of terrorism. The United States adopts a generic cut-off with few moorings, as presented in the United States Code of Law, which represents the compilation of all permanent US federal statutes. They also differentiate international and domestic terrorism.

Unfortunately, because it has a generic content, a high number of acts can be considered as terrorism in the United States. The influence of public opinion and politics on issues that directly affect national security is increased.

In addition, the French approach includes the prediction of concrete ways in which acts of terrorism can be carried out, reducing political influence in their practical consideration of States.

However, it is also dangerous to limit the conceptualization from a strict exemplification. In order to limit the scope of terrorism, Brazil, unfortunately, was not consistent in limiting terrorism based on hypotheses not included in the scope of the standard. It is it correct to regard as terrorism only acts in the political sphere, since other aspects, such as religious and ethnic, also lead to the practice of terrorist acts.

Finally, the English example is a good one in progress over the conceptualization of terrorism. On it, acts provoked in electronic means, like Internet, were included in the hall. The elevation of international organizations to the possibility of being victims of terrorist attacks and the punishment for preparatory acts or the use of threats of terrorist attacks that have not yet materialized, so important for the prevention of terrorist attacks, also appear as English innovations.

After analyzing the legal provisions, it is possible to perceive that all are concerned to highlight common elements that should guide the construction of a definition of terrorism: its international aspect, without being bound to any specific territory; as well as the possibility that any person or group of people can be considered as victim of terrorist attacks. In addition, the desire to promote a scenario of uncertainty in order to put pressure on its victims to take a determined stance is a common element of the countries definitions.

Therefore, following the above considerations, a proposed definition for terrorism would be: any action or threat of action using direct or indirect violence, by any means, whether physical or virtual, and which provokes disturbance to public order by means of terror and the use of ideologies in order to coerce or pressure political, economic and social actors, or to harm the community and the environment, with the exception of the politically peaceful manifestations.

\section{Terrorism in a struggle perspective}

Guimarães (2007) understands that the main objective of Terrorism is to create Terror due to determined motivations - that may be politico-social, or cultural-religious. It is possible to reach a political objective, but it is not determinant to characterize a terrorist act, because its aspiration is to cause Terror, threat and fear in the community.

The growing number of terrorist attacks, as those which occurred on September 11th/2001 in the United States; and the massacre of journalists of the Charles Hebdo Magazine in France on January 7th/2015, led to a different approach on the subject, taking into account important issues of International Politics.

It must be noted that Terrorism can be executed for a variety of reasons and can be practiced by one individual or a group of people. It can also be encouraged by a State 
that uses this practice as an instrument to impose its political and economic interests (State Terrorism), with disrespect to the political, diplomatic and economic regulations established and consolidated as results of States relations and discussions in Multinational Organizations.

Souza (2008) argues that State Terrorism consists in the disrespect of individual or collective rights based on institutional arguments, such as the maintenance of governmental regime, using systematically Terror as a pattern - creating an unstable environment to benefit. The author points out the inefficiency of protective legitimacy against terrorist acts or undeclared wars as an exemption for countries on carrying out State Terrorism.

When an attack occurs, the Media often discusses the political effects promoted by this event - whether the States involved will impose sanctions against one or another; how this will impact the diplomatic relations among countries allied with this king of practice; and, in more extreme situations, if this will lead to a State Intervention in order to dismiss a government regime.

However, usually there is a lack of economic analysis in order to ascertain the level of disruption over the diplomatic commercial relations of those States involved, either directly, with the closure of commercial relations; or indirectly, after trade weakening promoted by a group or group of countries linked to the parts involved on Terrorism.

In addition, Terrorism has been fought as the worst crime in a cosmopolitan environment. Often, historical traits, disruptions of State sovereignty and genocides are ignored as the possible sources of it, even if, in many cases, it is associated with new means of political struggle that rises due to the lack of force to dismissing regimes or systems using democratic precepts or inclusive participation.

In a microeconomic scenario, Germaud and Fernandes (2003) consider that terrorism cause a contestation growth and repulsion to what is considered cultural enemies. At the same time, a macroeconomics analysis involves State economic policies chosen after Terrorist events in favor of economic expansion or contraction in order to reestablish status quo.

According to Germaud and Fernandes (2003), fundamentalist practices tend to grow linked to nationalism with the enemy finding, especially when terrorist attacks cause invasions in the country - migratory flows or military inspection. In that direction, moderate and West-related groups tend to lose space in politics. The country starts to act in opposition to globalization, closing itself associated with an internal strengthening.

The current possibility of defensive war acceptance by the United Nations only legitimizes the invasion, but does not take the State identity of who is taking the action. Once it is approved and carried out by an International Organization, the enemy faced by terrorists will be depersonalized. This promotes confusion and attention dispersion that leads to an easier combat of terrorism.

Indeed, political offense reached the Modern World and the twenty-first century. Quijano (2000) explains that the creation of races played a form of domination when modernity started to rise. The author also points the racist pattern of the dichotomy East and West in comparison to the social white and black people segregation.

Due to the unsuccessful of Europeans on imposing Eurocentrism to the East, Quijano (2000) states that the solution found regarded the production of knowledge as a form of marginalization - considering non-European scientific theories and experimental 
constructions as non-science. This marginalization was also perceived in other areas, such as religious, political, economical and environmental.

This approach was the main difference brought by Quijano (2000) among the European domination model and other pre-existing forms of social organization, like the Egyptian and the Mesopotamian. The European way imposed its own concepts of domination over the world using Coloniality of Power, the Capitalism system and Eurocentrism; while others did not have domination as a goal.

Quijano (2000) adds to his comments the paradoxical feature of European marginalization, explaining that the most developed region during the Roman Empire was the Muslim-Jewish region, birthplace of various modern practices, such as salary wages.

The constant polarization between Eastern and Western led to conflicts and insubordination that directed individuals and groups to use more violent and burdensome devices, even against civilian targets after the development of more sophisticated forms of control and the use of force - outlining the practice of Terrorism in modernity and postmodernity eras.

\section{The influence of the Eurocentric paradigm on international law}

Eslava et al. (2017) point out the Westphalian Treaties, known as the Westphalian Peace, as the hallmark of separation between modern State and the Catholic Church, giving birth to the Modern International Legal Order marked by the coexistence of multiple territories defined by autonomous units.

Although conferring self-determination rights, Eslava et al. (2017) also highlight negative aspects of this historical moment, mainly due to the fact that this separation came from rational and modern perspectives. According to the authors, International Law and the Modern State are in mutual support that do not ensure material equality among different people.

In this context, Quijano (2000) elucidates the ambiguous and contradictory character of modernity - at the same time that it preaches hierarchical reduction and equality among people, it gives the role to regulate the limits of social equality and of modernization process to the market.

In this sense, Anghie (2005) affirms that International Law is a colonial product and that international juridical structure does not know how to incorporate different perspectives, problem that generates exclusion. But this fact was unassisted in the Academic level.

Eslava et al. (2017) say that only at the Bandung Conference, in 1955, the oppressive character of the concepts of Nation-State and of International Law became evident. At that time, political and legal structures related to social differences and to racism were not apart from these concepts.

Eslava et al. (2017) mark the Bandung Conference as the meeting of those who have been rejected by the Western World - starting an anti-hegemonic movement that claimed national sovereignty and cultural resurgence of the excluded nations. In addition, after the Bandung Conference, some positions emerged in opposition to the interests of the Security Council in official Assemblies of the United Nations.

In this sense, Alvarez (2010) gives some criticism over the United Nations Security Council for turning the war on Terrorism as one of the main discussed themes, what he considered a symbolism of restraining the resistant movements in general. 
Indeed, Eslava et al. (2017) argue the understanding of national development as economic progress acquired in political independence, overcoming the rhetoric present in International Law that insists to defend the sense of union acquired through the collectivist consciousness of nation, made possible after adapting the international jurisdiction to local contexts. This maintained the colonial feeling and the centrality of the European legal heritage.

Eslava et al. (2017) also bring problems arising from the conclusions reached at the Bandung Conference: determinism of sovereignty. It granted wide freedom to national governments, culminating in internal political distortions and excesses, accumulation of debts, environmental degradation and exploitation of domestic economy.

Even this change on the international treatment of Law did not necessarily give greater freedom or participation to local populations, favoring the disbelief on the emancipatory and transformative role of International Law. Abraham (2014) argues that this situation reinforced the understanding of postcolonial States as dominant national majorities over cultural and ethnic minorities, favoring the occurrence of violence.

Eslava et al. (2017) agree with Abraham (2014) and assert that the fetishization of the Nation-State as the only actor that could make social changes leads to repression of internal minorities and to an extension of the colonialist and neocolonialist narrative. Even though the Nation-State was important for self-determination, it provided a limitative approach on it, once the elites subdued the minorities, maintaining the colonialist tradition.

With the aim of proposing a new context to the Third World project, Eslava et al. (2017) defend a re-reading of the paradigm that arose in Bandung to a construction more distant from the State, but that remains anti-imperialism, questioning constantly the State role. The authors use the period of the Arabic Spring as an example to strengthen their argumentation, when progressive and revolutionary movements were valued by this logic.

Finally, Eslava et al. (2017) point solidarity against imperialism and violence sanctioned by the State as a matter of choice. They assume that alliances, although do not construct the best solutions, are mechanisms that have a transformative power.

Despite the pacificator speech of Eslava et al. (2017), it is not clear if eventual terrorists ruled by oppression feelings will accept the solidarity approach and feel integrated. But, because of the lack of empirical results, this may be an alternative to alleviate the problem of Terrorism.

In accordance, Chimni (2006) mentions the pressure made by economic relations in order to break country boarders even when they would not take into consideration the needs of Third World countries. At the same time, this break confers economic sovereignty to international institutions such as the World Bank, the International Monetary Fund (IMF) and the World Trade Organization (WTO).

Chimni (2006) says that these institutions intervene on these countries incisively using the speech of financial and economic management inadequacy and inefficiency on controlling internal conflicts. This intensifies national aversions to imposed standards coming from Post-Colonialist or Imperialist perspectives.

In this sense, Quijano (2000) proposes Transmodernity as an alternative to the concept of modernity coming from Eurocentrism marked by the construction of individual egos in all parts of the world, and not only in Europe, birth place of 
modernity. The assumption of this idea incorporates respect to what is considered different and contributes to the affirmation of national identities using other methods beyond violence.

Through this concept, Quijano (2000) states that the inclusive way of thinking recognizes the importance of integration of new people in the new World System and of building a new standard of world power, answering demands of resistance movements.

Ordinarily, Law review is listed as the main activity to guarantee the success of resistance movements. However, not only this needs to be reviewed. Rajagopal (2002-2003) argues that Liberal and Marxist theories are also insufficient to ensure the inclusion of non-state actors in the decision-making process and in the construction of the national will.

According to Rajagopal (2002-2003), political liberal theory assumes unity of social actors and creation of formal spaces where the interests of these actors can be defended. The critique of it involves the fact that, in Third World countries, there is perceived a plurality and heterogeneity of actors, but the model of representativeness does not demonstrate it. In other words, the unity created after the union of individual wills do not create a result that fits everybody's participation. Some authors are excluded and marginalized in this process.

In addition, criticism on liberalism encompasses the harmonic economic growth ruled by the State. This, according to Rajagopal (2002-2003), leads to colonization of civil society, urging social movements as a way to liberate them from State domination.

On the other hand, according to Rajagopal (2002-2003), Marxism is incomplete because it also defends a unified political arena. Another bad aspect is the consideration of the State as the main change-maker author on social and economic realities, being the mass mobilization an instrument to grant State power.

Social movements, as Rajagopal (2002-2003) alludes, disagree with the changes conducted by the State. They wish to build their own political spaces. Added, Marxism lost connection with new economic arrangements after the incorporation of labor and natural resources in the production model of Marxist theory, making necessary an update.

Due to all that was discussed, Terrorism urges as a phenomenon that opposes to legal integration, mainly after the start of an Interventionist Economic Agenda, always regarding the rebirth of nationalism, especially in countries marked by historical periods where this configuration led to social catastrophes and genocides, as Germany, Poland and Hungary.

In addition, the tightening of anti-terrorist measures has been discussed in countries such as France, Austria, Germany and England with regard to the closure of borders and controlling migratory flows. In this direction, national solutions found individually by each nation do not collaborate with the maintenance of integration within the European Union. The issue of Terrorism has been faced as one of the most controversial ones in Europe nowadays, being able to contribute to the split of the bloc.

In ancient history, disputes were solved through declarations of war, the use of force, and alliances that led to victories and to share the power conquered among victors. Thus, for Mearsheimer (2007), the constant possibility of war did not generate a permanent state of war, but a constant preparation for it. Duarte (2012, p.07) points out that "the activity of preparing the national defense of a country is an intrinsic necessity as a consequence of the anarchic condition of the international system". 
However, after the damage caused by World Wars, the International Community moved towards the promotion of peace. It mediated the creation of institutions that guarantee peacekeeping, either through the regulation of the United Nations or through International trade rules protected by the World Trade Organization.

With similar opinion, Mazzuoli (2011) argues that, since 1815, International Solidarity began a change in the international scenario through the creation of multilateral courts and of permanent International Organizations with capacity to conclude treaties with/on the side of States.

Nowadays, power is consolidated and protected no longer by the use of force, but by the threat of technological warfare devices with very high lethal power. In this sense, Ferreira 1982 (apud Duarte 2012, p.07) argue that new technologies generate expectations of military superiority in international relationships, generating different perceptions of vulnerability or protection.

The universality of rights brought by International Law and apparently positive for the inclusion of marginalized people in the process of globalization can also be dangerous. Galindo (2016) points out that, although universal, International Law emphasizes civil and political rights, but do not universalize economic, social and cultural rights. The universality of rights serves also as a problem to its applicability - oppression of rights universality (Galindo 2016, p. 12).

Rajagopal (2002-2003) explains that the focus of legal research on finding conflicts and gaps in Law, rather than building an ideology, gives a static aspect to the legal system, as well as contributes to the weakening of the authority of Law.

If an ideology was attempted to be constructed, the rule of Law would have a better understanding on resistance groups - and they would be able to participate in this construction, discouraging them to practice Terrorism. Escobar (2007) says that, in this scenario, Transmodernity is a central concept, encompassing the ethics of liberation through the action of subaltern groups.

Galindo (2016), however, does not use a total criticism on International Law. He recognizes that it has a transformative power. In order to achieve that mission, therefore, it must find an adequate way to employ resistance in transnational level and in social movements.

\section{The resistant movements perspective}

Gathii (2011) holds a more radical position and asserts that the power of Europe and the United States produce structures of domination that persist until today (dominant languages and religions) - a result of the replication by the former colonies of the Western State model. Such structures are rooted in the core of the States and has been already added to the cultural path of these societies.

Rajagopal (2003b) argues that some forms of resistance are legitimated, while others are not, and that this decision comes from those who are in the exercise of power. Under this view, Terrorism could be a form of resistance not legitimized, being widely criminalized and serving as a scapegoat to demonstrate to other forms of resistance that, if they are not legitimized, they would receive equivalent treatment.

Among the legitimized resistance forms, Rajagopal (2003b) states that Human Rights are filters that gave legitimacy to the forms perceived in the Third World. The author 
also states that Human Rights are the main form of resistance accepted by Colonialism and Imperialism.

Rajagopal (2003b, p. 05) concludes his digressions highlighting the necessary elements to build a theory of resistance: the exercise of power re-articulation within the International sphere; the nature of human liberalization aimed; the relationship between reformist and radical resistance; and the plurality and fragmentation of diverse States.

To go further in the discussion, Rajagopal (2002-2003) shows the role of social movements in proposing multiple spaces in politics having community as the main agent. A multiplicity of arenas allows more voices to take over and exert their space of influence, democratizing societies and attenuating the sense of external exploitation/oppression.

Thus, Rajagopal (2002-2003) values political culture as a decentralized phenomenon that brings together struggles for power in the private, social, economic and cultural arenas. There, decisions are taken collectively - below the State level and above the individual level.

Rajagopal (2002-2003) argues that conflict is at the heart of Politics, and that the model of class harmony from Liberalism must be denied because conflict adds social justice to the analysis of institution and international economic law norms. In addition, the author points that identities are not derived from individual choices, but from the dynamic relational activity of different groups in pursuing a common goal.

This paradigm shift is very interesting to the struggle on Terrorism. When the International Community perceive that the universal peace model is inefficient, it will may be appropriate to assume that there are conflicts inherent in societies, and, at that moment, politicians will seek alternatives that do not have peace as an objective (but as consequence of social harmonization), and that aims to conciliate interests of different groups.

Nowadays, the new balance of power is legitimized by institutions as the United Nations Organization and the World Trade Organization. On this level, it is harder for those who wish to gain power, as the power struggle does not occurs in a regional level anymore.

According to this new distribution of power, new forms of struggle for ideals and ideas have emerged. In this perspective, Allenby (2015, p.71) preached that "the wars of militaries are over; the wars of civilizations have begun" since they involve not only political and military disputes, but also lifestyles and areas of influence.

In this direction, Rajagopal (2003a, p. 408) returns his analysis of resistance movements to social movements. Beginning his digressions, the author points the requirements of a social movement: to involve informal networks of interaction among the plurality of actors; to be involved in political or cultural conflicts; and to organize itself based on common beliefs and collective identities.

According to the requirements presented by Rajagopal (2003a), terrorist groups or associations could also be considered as social movements. This discussion is rather difficult and was raised in Brazil during the debates on the Anti-Terrorism Law - it had too general paragraphs defining Terrorism - allowing interpreters to consider certain organized movements as terrorists and to legitimize the use of Law as a form of political persecution against social movements. 
In this sense, Rajagopal (2003b) argues that Law continues to ignore the dynamics of resistance movements. Instead, it considers them bodies of legal rationality that need repression. Therefore, Law and Institutions seem to be dependent on resistance, having a limited scope of action if it does not exist.

Historical scenarios explain the stronger treatment given by Law to resistance movements. Rajagopal (2003b) affirms that International Law priories resistance on the scope of self-determination. This allowed colonial authorities to consider resistance as a criminal act and to combat it with the tightening of legal rules.

In addition, Gramsci (1971) tells the conclusion that social movements led to a discussion of various issues, such as Human Rights and Democracy. They have resisted to government decisions, but have not been able to oppose international affairs, usually decided by consensus.

Coming from a national to an international perspective, it is important to point that areas of influence are not exercised only within States, but also between States. Usually, the powerful countries influence the weakest ones due to their greater bargaining power in the international scene, enabling decision-making by consensus.

In this context, the ideological struggle is positive, because when men stop to dream and to seek a better quality of life, living loses it meaning and becomes survival. The problem arose when these legitimate and positive struggles overcame the limits of what was acceptable within a society and began to affect other people completely unrelated to them.

The belief that struggling emancipates people in a personal and collective way was first brought by Maquiavel (1515, p.86): "a prince must therefore have no other purpose. (...) But the war and its organization and discipline. (...) it is of such virtue that it not only keeps those who were born princes, but also (...) makes men of private condition ascend to that post".

Over the years, the absence of dialogue and fundamentalism intensified conflicts and caused the growth of terrorist organizations that do not care about their victims, as it could be seen after some executions of the Islamic State in Iraq and Syria (ISIS), with the purpose of beating political targets.

This event, according to, has created an abstract, confused and hard to determine enemy for internal and for international public opinions - controversial response. However, in a fair and socially balanced society, it is needed conciliation of different interests that allows a pacification of social conflicts to achieve a stage of peace, one of the principles of the Federative Republic of Brazil in International Relations - 4th article of its Constitution (BRASIL, 1988, w.p.) - and of United Nations - 1st purpose, Chapter I: Purposes and Principles (UNITED NATIONS 1945, w.p.): "to maintain international peace and security".

The confused enemy is one result of multifaceted Terrorism. Rezende (2013) highlights it as a historical phenomenon, marked, initially, by the State use of force with no limits instead of guaranteeing the security of its population.

Indeed, Rezende (2013) affirms that groups that question the legitimacy of a national authority or its independence based on cultural aspects cannot be considered terrorists, but guerrillas, separatist movements or insurgents, even though they use violence as an instrument. In this way, the author considers situations in which violent practices aimed at reaching a political target are not considered as Terrorism. 


\section{Third world approaches to international law}

Galindo (2016) points one of these practices of national authority defense based on cultural aspects that are not Terrorism, but a theoretical and academic movement: the Third World Approaches to International Law (TWAIL).

In communication, Gathii (2011) suggests that TWAIL arose from a group of graduate students at Harvard University who highlighted new challenges and models for International Law marked by criticisms of formalism, of neoliberal policies and of sovereignty that gravitated around international jurisdiction.

In addition, Gathii (2011) debates the paradoxical aspect of International Law because, while guaranteeing sovereignty, equality and self-determination, it bears imperialistic and colonial influences providing little participation to Third World countries.

Galindo (2016) affirms that the movement was influenced by post-colonialist studies - marking historical facts of decolonization and sovereignty conquest, as well as new imperialist context of economic and political domination. TWAIL was marked by three phases.

Before getting to the specific phases of TWAIL, it is important to list the goals of this movement. Among them, the first one brought by Mutua (2000, p. 31) was the understanding and deconstruction of International Law use as a mean to create and to perpetuate a rationalized hierarchy of international norms and institutions.

To achieve this goal, Mutua (2000) shows the desire to construct and to present an alternative legal system to international governance in order to eradicate underdevelopment conditions in Third World. Okafor (2005) adds equity and fairness to TWAIL's goals, highlighting the ethical aspect of opposition to forms of inequality and injustice at international level.

Gathii (2011) argues that the aim of TWAIL is to challenge International Law offering participation to Third World countries in the international scene; and to criticize policies of marginalization and domination without hierarchy. In this sense, TWAIL is an encounter of academics that converged on the need to include these countries in the international arena.

Once these considerations have been made, the study of TWAIL phases should be started. In the first phase, according to Galindo (2016), colonial international law that subjugated the oppression suffered by Third World populations was discussed. The result of this phase came to a conclusion that non-European people tried to identify themselves with international jurisdiction, demonstrating ideas of cooperation and emancipation using norms of International Law in their favor.

In addition, Galindo (2016) emphasizes incompleteness of the priority given to the principles of sovereignty, equality among States and noninterventionism to guarantee the independence of these countries. The main reason for that was the need for change on economic structures - creation of the New International Economic Order (NOEI). The focus was the Nation-State and how the most powerful countries used International Law to maintain their hegemonies.

On the other hand, the second phase of TWAIL, according to Galindo (2016), began in 1997, disregarding the centrality of State and of sovereignty. At that time, emphasis was given to violence within the post-colonial States and to the consequent importance of their internal actors, situation that contributed to the growth of terrorist attacks. 
Galindo (2016) states, at this stage, the questioning of the International Institutions role, because: 1) their agendas produced domination over internal state actors; and 2) colonialism was recognized as one source of International Law, a paradox that still exists today in the immigration policies of countries like the United States and France comprehension that foreigners are people who need to be taught culturally and behavioral in order to be part of their societies.

Finally, Galindo (2016) concludes the second phase describing its interdisciplinary character - maintenance of civilizing ideals even in proposals that seem to be humanitarian, such as good governance, Human Rights and Democracy. The marginalized groups and the treatment over them played by International Institutions to maintain social hierarchies were discussed, highlighting the collapse of international organizations ability to deal with minorities and Terrorism.

Related to the topic, Gathii (2011) argues that liberal models usually allows questions on authoritarian governments by the attribution of civil and social rights, but this does not promote a profound governmental reform. The policy of interests exchange also rules International Law, creating a certain kind of immunity to authoritarian and totalitarian governments after fulfilling International Law Agenda.

The third phase of TWAIL started after the terrorist attack on September 11th. According to Galindo (2016), it brought back the State centrality, as well as its relations with Terrorism regarding the combat or the support given to it. One criticism highlighted by the author that has shown the disregard of Third World countries was the fact that it was given attention to rewriting norms of International Law to legalize the legitimate preventive defense using force only after the explosion of airplanes in one of the most powerful nations, even if Third World countries have been dealing with Terrorism for much longer.

After the separation of TWAIL in phases, a criticism faced by Galindo (2016) was that TWAIL's periodization in phases can subvert its International Law project, once a the a new paradigm construction discourages the study of previous paradigms, then interrupting the evolutionary cycle that was reached and favoring the relations of domination.

However, there is no evidence of the previous assertion because dominating relations can be externalized in different ways and may have different levels of intensity. Due to this dynamism, new relations can lead to new paradigms that keep the importance of previous ones. The opening for movement changes is extremely important to keep its proximity with the object of analysis.

Indeed, Alvarez (2010) attributes a nihilistic character to the TWAIL movement due to the absence of a propositional model. The author affirms that it does not have a positive Agenda to reform International Law norms. This would fade the emancipatory character of international jurisdiction, making other resistance possibilities - like Terrorism - be seen as more successful to confront imperialist power.

Alvarez (2010), in spite of the criticism added to his comments, recognizes that colonial patterns of thought continue to structure primordial concepts of International Law; that racism and conceptions of cultural superiority continue to weaken the contributions of non-European people; that the economic and commercial concept of class remains central to understanding legal regimes; and that contemporary forms of globalization have taken geographic notions of imperialism and hegemony into forms of collaboration, all theoretical arguments of TWAIL movement. 
Gathii (2011), in opposition, argues that TWAIL has an Agenda of transformation for International Law coming a language of oppression to a language of emancipation that reflects Third World struggles, guaranteeing global justice.

In addition, Alvarez (2010) highlights the incorporation of minorities and subaltern groups of developed countries to the theory of TWAIL. It would be disrespectful to ignore oppression suffered by these people after an analysis of the Nation-State with no regard to their internal structures. On the other hand, there are also powerful elites in Third World countries that are part of the Dominant cosmopolitan class and that do not suffer oppression at all.

However, Gathii (2011) emphasizes International Law reform defended by TWAIL not necessarily through the use of power by countries, because it can generate more negative externalities than the benefits in a short term period, as it was perceived during the colonization process. This statement, however, does not put the use of force totally apart.

The TWAIL opening rhetoric regarding the use of force when necessary is very dangerous and does not show a clear position of it related to Terrorism. The necessity analysis runs through subjective elements, which are also taken into account, for example, when a terrorist attack is planned. On the view of Terror agents, the act is necessary in order to achieve some objective that would not be possible using peaceful instruments.

If the use of force is accepted, it would be a contradiction to stand against it when small groups made use of force mainly because, according to TWAIL, these cells are subjugated by the International Order. If powerful nations would be able to use it when necessary, sometimes with obscure or undeclared interests, the same statement should be applied for weaker actors. It is not understandable to demand demilitarization and peace in a global society marked by arms race and the sense of latent war. Thus, the use of force should be avoided, whether at the national or international levels.

Almost in response to the previous discussion, Gramsci (1971) offers a peaceful solution: the passive revolution. It would be effective through an efficient and interpersonal way of articulation between groups when it was not possible to directly address the regime using force.

For a better understanding, Gramsci (1971) brings the difference between war of movement and war of position. On the first, victory would initially appear at the civil society and only later at the State level; whereas the second points a frontal attack against institutions of hegemony to guarantee control over them.

In this sense, terrorist attacks would be linked to the idea of war of movement, while acting in Non-Governmental Organizations (NGOs) would be driven by passive revolution and war of position.

\section{Terrorism and globalization}

Rezende (2013) places Terrorism as a probable result of globalization - it denotes cultural, ideological, political differences and social exclusion (people who faces prejudice and disrespect feel like they were less important). This feeling is common, especially in the Western world, where there are seen manifestations of prejudice against Islamic, 
Jewish and Black people. Sometimes, the social issue makes Terrorism urge as a way to be respected and to impose ideas on a world-wide level. If not, at least it makes these groups feared, conferring a certain status to them.

In that direction, globalization puts territories closer and facilitates interconnections among countries to increase trade relations, at the same time that brings a negative effect of competition and domination at a global level.

Quijano (2000) states globalization as the completeness of American domination process and of modern world capitalism, reaching world hegemony after spreading the Eurocentric vision.

Thus, Quijano (2000) advocates the creation of a concept for race as a way of exercising control and domination, building structural and social differences among different social categories. In this way, globalization would be the culmination of an oppressive and disrespectful process towards marginalized populations.

Having a different vision on the topic, Escobar (2007) brings the discussion about globalization to a different level - the stage of globalization. The possibility raised by the developmentalist movement argues that globalization is the last stage of capitalism. The antagonistic possibility treats globalization as the beginning of a new system. Escobar (2007) says that, if the first possibility is correct, legitimacy through international law confirms the oppressive character guided by it.

A breakthrough approach to overcome the oppressive character of International Law was pointed by Eslava et al. (2017) after the Bandung Conference. According to the authors, the conference document, called Communiqué, brought a trans-civilizational perspective - cooperation among the multiple civilizations and religions - being marked as a start of a new paradigm, dubbed Spirit of Bandung.

Eslava et al. (2017) argue that this Spirit was perceived in the following Conferences and has marked the decolonization movement. Its importance was mainly related to the union of formalism and subversion, bringing a theme that was previously treated in the margins of the Official Political Agenda to the international political scene.

However, Galindo (2016) considers the negative point of the movement from Bandung in the term Third Worldism - it promotes an homogenous character to the Global South that ignores the marginalized populations of the developed countries. According to him, the Southern states suffered differently from colonialism and postcolonial relations, having diverse structures that cannot be fought by a single Universalist front.

Chimni (2006) disagrees with the negative use of the term because its use would be necessary to show connections of those who had their histories marked by colonial subjection, therefore struggling hegemonic policies. In addition, the author points to the elites' attempt of deconstructing common roots of movements as a way of weakening them, which would be favored by Galindo's argument (2016), or to weaken the adhesion to resistant movements for having a common claim.

This change of scope, according to Rezende (2013), brought a different treatment to Terrorism, since it passed, after the Geneva Convention, to receive a humanitarian approach terrorists are now under regulations of International Law. Thus, the first parameter of struggling Terrorism in the internal scope of States has been surpassed to reach an international regulation that binds anyone at anyplace, favoring punishments for this dangerous practice.

In the North-American case, Shapiro (2012) alludes to the fact that globalization, while brought greater economic development, also increased the possibility of the 
United States security being affected in more countries and regions, forcing the country to increase partnerships and to toughen security relations and policies. The author brought the speech of Hillary Clinton, former North-American Secretary of State, which stated that coalitions are becoming more complicated and, at the same time, crucial.

Therefore, the growing number of countries that want to celebrate security agreements with the United States, according to Shapiro (2012), means a unique strategic opportunity for the country to continue in the international centrality on security and military issues. However, challenges on cutting the Department of State Budget in economic crisis periods tend to limit American ability over the years.

After that, the perception of a protectionist environment after a terrorist attack is confirmed, not only after American government treatment on the subject, but also because of the permanent State interventionism in the sector almost 17 years after September 11th. In fact, it is perceived an economic policy extravasation to other State sectors, reaching even measures in the Foreign Policy Agenda.

Gould and Klor (2010) point out the increasing number of Terrorist attacks in the world. The authors explain this based on their supposed effectiveness over politics and economics - there are two antagonistic positions.

The first one justifies the growth of Terrorism because it is effective, especially in democracies (PAPE, 2003). The main argument is that electorate is sensitive to civilian casualties caused by terrorist acts, making the authoritie give grant concessions to terrorist organizations, whereas in authoritarian regimes this concern is not given strongly, once the rulers only care to please the ruling elite.

For the other position brought by Gould and Klor (2010), there is little evidence that Terrorism is effective and, according to Abrahms (2006 apud Gould and Klor 2010, p.1461), it is also ineffective against democracies because democracies have efficient mechanisms to combat it. They are also less likely to make territorial and ideological concessions than authoritarian regimes.

Abrahms (2006 apud Gould and Klor 2010, p.1461) came to this conclusion after analyzing the 10 countries with the largest number of victims of Terrorism, among which only two are considered free countries (India and the Philippines); while the others are non-free (Iraq, Afghanistan, Russia and Pakistan); or partially free (Nigeria, Nepal, Colombia and Uganda).

By coincidence, almost all the countries mentioned above are considered Third World countries - subjected to the process of colonization and imperialism. Foucault (1991) points that, in relation to countries in this category, power does not necessarily come from the State, but rather from the government apparatus above and below it, as well as domestic and transnational private actors.

Quijano (2000) explains the existence of elements of domination in every States, once the modern construction of Nation-State tries to homogenize the population through citizenship, having an antagonistic result - it promotes a more or less democratic path in the distribution of power control. The author states that citizenship is defined as legal, civil and political equality for unequal social agents who, therefore, do not have equal access to the spaces of power.

In addition, Foucault (1991) argues that the exercise of power has a bureaucratic aspect of monitoring and controling the poor population of Third World States, what 
could explain the high number of Terrorist Attacks in the mentioned countries that have the main numbers of victims of them.

In conclusion, Foucault (1991) emphasizes the micropolitics of power and its analysis on how individuals and groups, who would be less important than State actors by the division of power, experience their own power relations. The author believes that government practices can become foci of resistance, and can also serve as substrate for creating a terrorist mentality in resistance groups.

Altvater (1972) affirms that the State cannot be understood only as a political instrument or as social institution established by capital, but as a guarantor of the social existence of capital along and beyond competition. As a mediator of interest conflicts, it must act to coordinate and assist people in their decisions and projects, benefiting them not only as individuals, but as a community.

Pereira (1989) argues that State control on Economy, historically, is a cyclical process - at different times there are interventionism expansions and contractions. Therefore, an inert State, that uses the same type of control in any situation would be not be accepted, being mandatory for it to consider the economic and social conjuncture in which it is inserted.

At the same time, Pereira (1989) confirms that State intervention based on equality and economic efficiency should be supported, and that it does not, by itself, differentiate a policy adopted by conservatives or liberals, since conservatives often adopt policies interventionist economic policies.

Schapiro (2009) points that market failures give reason for State interventionism, and thought it, exchange problems among private individuals are remedied. Economic interventionism promotes rearrangements that can promote or hinder certain groups or, in general, a country.

The types of State interventionism are not stagnant and fit the needs perceived in each period. Pereira (1989) shows the four forms of state intervention: macroeconomic regulation, limited by centralized planning; microeconomic regulation, with rules of protection to the health and safety of consumers; managerial microeconomics, regulation on a case-by-case basis; and nationalization or direct production, aiming the abolition of private property above the means of production.

According to the relations of the State with the private companies, the intervention can be, according to Pereira (1989), limiting, when it imposes limitations, as taxation, regulation on health and environment; supporting, when it promotes tax breaks and subsidies; and neutral, considered almost impossible.

At the same time, intensity must also be taken into account when analyzing Interventionism. Pereira (1989) says that it is difficult to measure it, and that its analysis involves the participation of state expenses in the Gross Domestic Product (GDP), excluding the production State companies.

\section{Law and state interventionism}

Schapiro (2009) refers to the use of Law as a tool of interventionism, happening through regulatory measures in the economic domain, either through the obligation to disclose information, to control market concentrations, to rule price stipulation or to determine property rights. 
Schapiro (2009) also emphasizes interventionism through indirect and institutional regulations. In the first, the State stipulates rules and incentives for private activities, accrediting the results obtained to the limitations and incentives offered. In the second, the State acts as a direct and present intervening agent, acting in the markets and controlling several economic indexes.

All that discussed before raises doubts about the establishment of interventionist policies by States victims of Terrorism, despite the fact that some of its proclamations have met with the precepts of economic liberalism and the capitalist system.

In addition, this project seeks to understand if the protectionist stance is transient (regulating momentously a bad economic scenario) or permanent (determining the State's performance). The conclusions may be given by an analysis of academic papers and of changes in economic indicators after a terrorist act. Once the scenario of Terror is set, it becomes paradoxical that the United States adopted the model of permanent interventionism, even being the main country in defense of free trade.

In this sense, Oliveira (2007) highlights the theoretical duality related to protectionism, which contrasts Johann Gottlieb Fichte and Georg Friedrich List. According to the author, Fichte defends a state of optimum size and a nation managed through planning in purely commercial matters, convertibility of currencies and the necessity of a minimum territory to economic self-sufficiency. As can be seen, he believed in permanent protectionism, in which the State would be an active agent in economic scenario.

In contrast, Oliveira (2007) explains that Friedrich argues that protectionism works as an instrument to achieve the construction and development of a strong nation that can make businesses in an active free trade scenario. That is, for him, protectionism in a transient way. The author also said that protectionism works in an educative way, so countries, after getting the know-how using protectionist practices, will be able to act safely in international trade.

\section{Conclusion}

The resistant movements need to be on regard of the problematic of terrorism to avoid being treated by the International Community as insurgent or rebel groups. Instead of blaming the historical roots or exploitation for their poor realities, the Southern are trying to solve their differences and delays and to give dignity to people through legitimate movements that adds social justice to the Third World countries.

Even though the noble character of economic state intervention coming from terrorism, which can get a continuous character, it can be seen that it does not always achieve the social justice concept. And worse, may favor nationalist and xenophobic opinions.

This scenario calls attention to the need of caution of public managers to avoid a model that only serves as a catalyst of investments in the military sector and to gain votes, without an effective Counterterrorism approach.

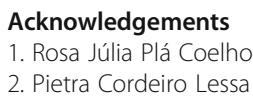




\section{Publisher's Note}

Springer Nature remains neutral with regard to jurisdictional claims in published maps and institutional affiliations.

\section{Author details}

${ }^{1} 93$ Lopo Gonçalves Street - Cidade Baixa, Porto Alegre, RS Zip Code: 90.040-000, Brazil. ${ }^{2} 80$ João Pessoa Avenue Centro Histórico, Porto Alegre, RS Zip Code: 90040-001, Brazil.

Received: 17 July 2017 Accepted: 2 October 2017

Published online: 13 October 2017

\section{References}

Abraham, Itty. 2014. How India Became Territorial: Foreign Policy, Diaspora, Geopolitics. Stanford (United States): Stanford University Press.

Allenby, Braden R. (2015). The paradox of dominance: The age of civilizational conflict. Bulletin of the Atomic Scientists, 2015, vol. 71 (2), p.p.60-74. Available at: http://web.b.ebscohost.com/ehost/pdfviewer/pdfviewer?sid=dc50c6ef128e-49a3-8ffa-49c6e419e2b4\%40sessionmgr115\&vid=1\&hid=110. Accessed on: April 5 ${ }^{\text {th }}, 2017$.

Altvater, Elmar (1972). Notes on some problems of state intervention. In: Kapitalistate, no. 1, 1973 (pulicado originalmente em alemão, 1972).

Alvarez, José E. (2010). My Summer Vacation (Part III): Revisiting TWAlL in Paris. 2010. Available at: http://opiniojuris.org/ 2010/09/28/my-summer-vacation-part-iii-revisiting-twail-in-paris. Accessed on: April 14 th, 2017 . Edgardo Lander, ed. La colonialidad del saber. Buenos Aires (Argentina): CLACSO.

Anghie, Antony. 2005. Imperialism, Sovereignty and the Making of. International Law: Cambridge (United Kingdom), Cambridge University Press.

Chimni, B. S. (2006). Third world approaches to international law: A manifesto. International Community Law Review.The Hague. Vol. 8. № 1, p. 4-5.

Duarte, Érico Esteves (2012). Conduta da guerra na era digital e suas implicações para o Brasil: Uma análise de conceitos, políticas e práticas de defesa, Texto para Discussão, Instituto de Pesquisa Econômica Aplicada (IPEA), No. 1760. Brasilia (DF), 2012. Available at: http://www.econstor.eu/handle/10419/91368. Accessed on: April 5th, 2017.

Escobar, Arturo. (2007). Worlds and Knowledges Otherwise: the Latin American modernity/coloniality research program. Cultural Studies, [s.I.], v. 21, n. 2, p.179-210, mar. 2007. Available at: http://dx.doi.org/10.1080/09502380601162506. Accessed on: June $3^{\text {rd }}, 2017$.

Eslava, L., V. Nesiah, and M. Fakhri. 2017. Introduction: The Spirit of Bandung. In Bandung, Global History and International Law: Critical Pasts and Pending Futures, ed. L. Eslava, V. Nesiah, and M. Fakhri, 1-32. Cambridge: Cambridge University Press.

Ferreira, Célio Lobão. 1982. Crimes Contra a Segurança Nacional do Estado. Rio de Janeiro (RJ): Liber Juris.

Foucault, Michel (1991). 'Governmentality', pp. 87-104 in Graham Burchell, Colin Gordon and Peter Miller (eds.) The Foucault Effect: Studies in Governmentality, Hemel Hempstead: Harvester Wheatsheaf.

Galindo, G. R. B. (2016). A volta do terceiro mundo ao direito internacional. In: BADIN, Michelle Ratton Sanchez, BRITO, Adriane Sanctis de, VENTURA, Deisy de Freitas Lima (Org.). Direito global e suas alternativas metodológicas: primeiros passos. São Paulo (SP): FGV Direito SP.

Gathii, JT (2011). TWAIL: Brief History of its Origins, its Decentralized Network, and a Tentative Bibliography. Trade Law And Development, Albany, v. 3, n. 1, p.26-64, sep. 2011. Albany Law School Research Paper No. 35 of 2011-2012. Available at: https://ssrn.com/abstract=1933766. Accessed on: April 14 $4^{\text {th }}, 2017$.

Germaud, Amaury Patrick Gremaud, Fernandes, Maria Fernanda Lombardi. (2003). Depois do choque e do pavor: reflexões acerca da Guerra do Iraque. Indic. Econ. FEE, Porto Alegre (RS), v. 31, n. 1, pp. 21-36, jun. 2003 Available at: http://revistas.fee.tche.br/index.php/indicadores/article/view/191/235. Acessed on: March 30th, 2017.

Gould, Eric D., and Esteban F. Klor. 2010. Does terrorism work? The Quarterly Journal of Economics. United States: Harvard College and Massachusetts Institute of Technology.

Gramsci, Antonio. 1971. Selections from the Prison Notebooks of Antonio Gramsci. New York: International Publishers.

Guimarães, Marcello Ovidio Lopes. (2007). Tratamento Penal do Terrorismo. São Paulo (SP): Quartier Latin, 2007.

Mazzuoli, Valério de Oliveira. (2011). Curso de Direito Internacional Público. $5^{\text {a }}$ ed. rev., atuali. e ampl. - São Paulo (SP): Editora Revista dos Tribunais.

Mearsheimer, J. 2007. A tragédia da política das grandes potências. Lisboa (Portugal): Gradiva.

Mutua, Makau. (2000). What is TWAlL? American Society of International Law Proceedings. Washington (United States), vol. 94

Okafor, Obiora. (2005). Newness, imperialism, and international legal reform in our time: A TWAlL perspective.Osgoode Hall Law Journal. Toronto (Canada). Vol. 43. № 1-2.

Oliveira, Ivan Tiago Machado (2007). Livre Comércio versus Protecionismo: uma análise das principais teorias do comércio internacional. Revista Urutágua - revista acadêmica multidisciplinar (DCS/UEM), n. 11, Maringá (PR), mar. 2007. Available at: http://www.urutagua.uem.br/011/11oliveira.htm. Accessed on: April 6th, 2017.

PAPE, Robert. A. (2003) The Strategic Logic of Suicide Terrorism. The University of Chicago. American Political Science Review, vol. 97, no. 03.

Pereira, Luiz Carlos Bresser. (1989). O caráter cíclico da intervenção estatal. Revista de Economia Política, vol. 09, n. 03, jul-set. 1989. Available at: http://www.rep.org.br/pdf/35-7.pdf. Accessed on: May 2nd, 2017.

Quijano, Anibal (2000). Colonialidad del poder, eurocentrismo y América Latina" In: Edgardo Lander, ed., La colonialidad del saber. Buenos Aires (Argentina): CLACSO.

Rajagopal, Balakrishnan (2002-2003). International Law and Social Movements: Challenges of Theorizing Resistance. Columbia Journal of Transnational Law, New York (United States), v. 41, n. 2, p.397-433.

Rajagopal, Balakrishnan. (2003a). International Law and social movements: Challenges of theorizing resistance. Columbia Journal of Transnational Law. New York. Vol. 41. № 2.

Rajagopal, Balakrishnan. 2003b. International Law from Below: Development, Social Movements, and Third World Resistance. New York (United States): Cambridge University Press. 
Rezende, Alessandro. (2013). Terrorismo: como defini-lo? Hegemonia - Revista Eletrônica de Relações Internacionais do Centro Universitário Unieuro. Unieuro, Brasília (DF), número 12, pp.76-86.

Schapiro, Mario Gomes. 2009. Novos parâmetros para a intervenção do Estado na Economia: persistência e dinâmica na atUação do BNDES em uma economia baseada no conhecimento. São Paulo (SP): Tese de doutorado apresentada ao Departamento de Direito Econômico e Financeiro da Faculdade de Direito da Universidade de São Paulo. Shapiro, Andrew J. 2012. A new Era for U.S. Security Assistance. The Washington Quarterly 35 (4): 23-35.

Souza, Fabianna Matias (2008). Delinquência Terrorista Nacional. Monografia apresentada como requisito parcial de conclusão de curso para obtenção do Grau de Bacharel em Direito pela Universidade Faculdade de Direito de Presidente Prudente - Faculdades Integradas "Antônio Eufrásio Toledo". Presidente Prudente (SP), 2008. Available at: http://intertemas.unitoledo.br/revista/index.php/Juridica/article/viewFile/831/808. Accessed on: April $21^{\text {st }}, 2017$.

Submit your manuscript to a SpringerOpen ${ }^{\circ}$ journal and benefit from:

- Convenient online submission

- Rigorous peer review

- Open access: articles freely available online

- High visibility within the field

- Retaining the copyright to your article

Submit your next manuscript at $\gg$ springeropen.com 